\title{
IbM PENGUSAHA KERUPUK KARAK DI DESA DUKUH UNTUK MENINGKATKAN KUALITAS MAKANAN SEHAT DAN PENERAPAN INOVASI TEKNOLOGI TEPAT GUNA
}

\author{
Bara Yudhistira1,2), Dian Rachmawati, Siswanti \\ 1) Pusat Pengembangan Kewirausahaan LPPM Universitas Sebelas \\ Maret \\ 2) Fakultas Pertanian Universitas Sebelas Maret \\ email: barayudhistira@yahoo.co.id
}

\begin{abstract}
Home industry of krupuk Karak in the subdistrict Mojolaban Sukoharjo district is currently growing with the number of many industries. Most of these industries still use borax as the developer material of batter dough. STPP is an alternative substance of borax replacement. STPP education as a substitute for borax should be done to eliminate the use of borax in food. Home industry in Sukoharjo district is still using manual labor for the production process of cracker karak. Appropriate technology can be provided to save time and production costs. The process of soaking batter dough has been the most timeconsuming and energy-consuming process. Mincer as a meat grinder can be used to crush the dough.
\end{abstract}

Keywords: karak, non-borax, Boyolali, training

\begin{abstract}
ABSTRAK
Industri kecil krupuk karak yang biasa dikenal dengan "karak" saja, yang ada di kecamatan Mojolaban Kabupaten Sukoharjo saat ini sudah berkembang/menjamur dalam artian jumlah industri ini sangat banyak. Sebagian besar industri tersebut masih menggunakan boraks sebagai bahan pengembang dari adonan karak. STPP merupakan salah satu alternatif bahan pengganti boraks. Penyuluhan STPP sebagai pengganti borak perlu dilakukan untuk menghilangkan penggunaan boraks pada makanan. Industri kecil karak di Kabupaten Sukoharjo saat ini masih menggunakan tenaga manual untuk proses produksi kerupuk karak. Teknologi tepat guna dapat diberikan untuk menghemat waktu serta biaya produksi. Proses pelumatan adonan karak selama ini yang menjadi proses yang paling memakan waktu dan tenaga yang banyak. Mincer sebagai alat penggiling daging dapat digunakan untuk melumatkan adonan karak.
\end{abstract}

Kata kunci: karak, non-boraks, Boyolali, pelatihan 


\section{PENDAHULUAN}

Usaha mikro merupakan kegiatan usaha yang dapat memperluas lapangan pekerjaan serta memberikan pelayanan ekonomi secara luas kepada masyarakat dan dapat berperan dalam proses pemerataan dan peningkatan pendapatan masyarakat, mendorong pertumbuhan ekonomi, serta berperan mewujudkan stabilitas nasional. Selain itu, usaha mikro adalah salah satu pilar utama ekonomi nasional yang medapatkan kesempatan utama, dukungan, perlindungan serta pengembangan yang secara luas sebagai wujud pihak yang tegas kepada kelompok usaha ekonomi rakyat, tanpa harus mengabaikan peranan usaha besar dan badan usaha milik pemerintah. Menurut Departemen Tenaga Kerja (Depnaker) usaha mikro adalah usaha yang memiliki kurang dari 5 orang tenaga kerja. Usaha Mikro Berdasarkan Undang Undang Nomor 20 Tahun 2008 tentang UMKM (Usaha Menengah Kecil dan Mikro) adalah usaha produktif milik orang perorangan dan atau badan usaha perorangan yang memenuhi kriteria usaha mikro sebagaimana diatur dalam Undang-Undang ini.

Salah satu UMKM di desa Dukuh adalah sentra kerupuk karak, produk ini merupakan produk makanan cemilan yang di konsumsi oleh masyarakat luas, karena produk ini merupakan makanan pendamping makanan pokok dan merupakan cemilan yang murah harganya sehingga

banyak orang yang mengkonsumsi, sehingga banyak UKM maupun UMKM yang bergerak di bidang itu. Dilihat dari proses produksi UMKM kerupuk karak, kebanyakan masih tradisional dan belum meninjau sebagai makanan yang berkualitas sehat atau belum ada ijin PIRT.

Industri kecil krupuk karak yang biasa dikenal dengan "karak" saja, yang ada di kecamatan Mojolaban Kabupaten sukoharjo saat ini sudah berkembang/menjamur dalam artian jumlah industri ini sangat banyak. Industri ini banyak terdapat di desa Gadingan, di desa tersebut terdapat sekitar 50 industri rumah tangga karak. Industri krupuk karak ini juga banyak terdapat di desa Dukuh di daerah itu terdapat sekitar 6 industri rumah tangga karak. Industri karak ini telah membentuk suatu paguyuban industi kecil dengan nama "Industri kecil krupuk karak kecamatan Mojolaban", dimana paguyuban ini setiap bulannya mengadakan pertemuan dengan salah satu kegiatannya adalah arisan. Di pertemuan tersebut digunakan juga untuk penyampaian informasi maupun tukar pikiran mengenai perkembangan produksi terkait dengan naik turunnya harga bahan disesusaikan dengan dimensi karak 
METODE

A. Kegiatan pengabdian kepada masyarakat ini menggunakan pendekatan kaji tindak.

Dalam kegiatan ini akan diterapkan beberapa metode yang sesuai untuk mencapai tujuan, yakni meningkatkan produktifitas dan efektifitas guna mengembangkan kualitas dan kuantitas produksi karak. Metode tersebut terdiri dari:

\section{a. Penyuluhan}

Metode ini dimaksudkan untuk menyadarkan pentingnya mendiversifikasi produk agar memiliki nilai tambah dan jangkauan pasar yang lebih luas, serta menyadarkan pentingnya meningkatkan keterampilan SDM, dan memanfaatkan peluang, khususnya berkaitan dengan program pengembangan sentra industri kecil di Kecamatan Mojolaban Kabupaten Sukoharjo.

b. Pendampingan

Metode ini dimaksudkan untuk secara langsung memberikan pelatihan tentang penggunaan bahan baku kerupuk karak sebagai makanan yang sehat yaitu salah satunya penggunaan bahan pengenyal yang ada ijin departemen kesehataan yaitu STTP (Shodium Tri Polyphospath) dan memberikan contoh-contoh operasional peralatan mesin pengepres serta pengrajang krupuk karak.

c. Praktek mandiri

Metode ini dimaksudkan untuk memberikan kesempatan yang lebih luas kepada peserta atau tenaga kerja untuk berlatih membuat komposisi bahan baku yang sehat, proses produksi dan potongan krupuk karak dengan mesin pengrajang krupuk karak. Dalam hal ini peserta dapat mencobanya atau melakukannya pada saat tidak bersama pembimbing.

\section{HASIL DAN PEMBAHASAN}

A. Koordinasi dengan Mitra dan Persiapan Pelaksanaan Kegiatan

Kegiatan yang pertama dilakukan adalah koordinasi tim pengabdian dengan mitra terkait dengan kondisi existing. Hal tersebut dilakukan agar terjadi sinkronisasi kebutuhan dengan UKM mitra. Dari hasil identifikasi masalah pada UKM mitra, masalah utama yaitu masih menggunakan boraks sebagai bahan pengenyal. Selain itu juga masalah sanitasi menjadi hal yang banyak ditemui.

B. Pelaksanaan Kegiatan Penyuluhan Pembuatan Karak yang Sehat dan Aman

Setelah dilakukan identifikasi masalah kemudian hal yang pertama dilakukan yaitu tentang sosialisasi atau penyuluhan tentang proses pembuatan karak yang aman dan sehat. Materi penyuluhan dititikberatkan pada penggantian bahan boraks dengan menggunakan STPP. Dalam hal ini masyarakat, khususnya UKM karak di Mojolaban belum mengetahui 
tentang adanya bahan yang dapat menggantikan boraks.

Pengenalan STPP sebagai bahan pengganti boraks tidak mudah, mengingat mindset masyarakat belum dapat menerima sesuatu yang baru. Apalagi hal tersebut menyangkut proses produksi yang tentunya akan berpengaruh pada efisiensi proses dan finansial. Penggunaan STTP terbaik menurut Astika (2015), penggunaan STPP terbaik yang masih dapat diterima konsumen yaitu $0,1 \%$. Pengenalan metode baru memerlukan waktu dikarenakan masyarakat perlu adanya pembuktian. Dengan demikian tim memutuskan untuk dilakukan trial penggunaan STPP di UKM mitra. Meskipun telah banyak penelitian yang berkaitan dengan STPP pada karak namun secara scale up dalam UKM belum ada, diharapkan karak yang dihasilkan sesuai dengan standar SNI 01-4307-1996 tentang kerupuk beras dimana penggunaan boraks tidak menggunakan sama sekali.

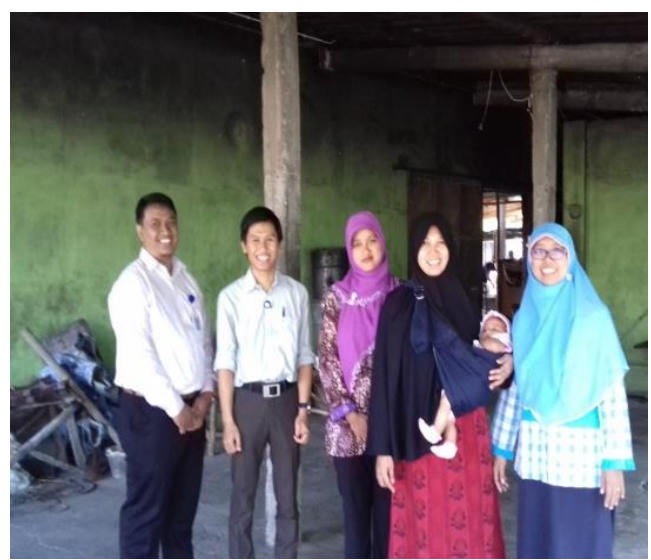

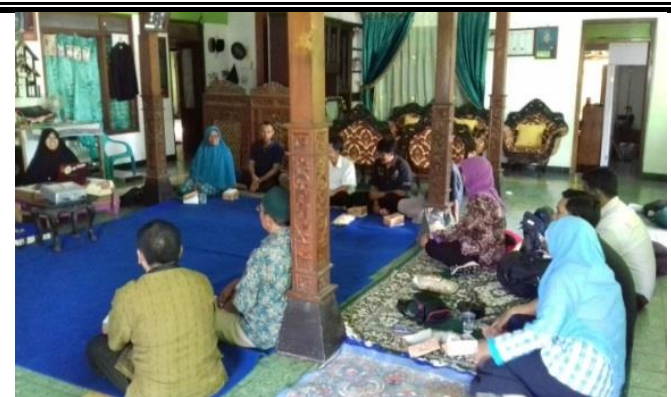

Gambar 1. Kegiatan penyuluhan proses produksi karak yang sehat dan aman

Kegiatan selanjutnya yaitu pembenahan fasilitas produksi terutama fasilitas yang berkaitan dengan sanitasi dan higienitas proses maupun produk. Salah satu fasilitas yang dibenahi yaitu dengan pembuatan cerobong tungku yang dilengkapi exhaust. Hal tersebut bertujuan untuk mengurangi polusi ataupun potensi terhadap produk. Selama ini yang terjadi yaitu proses penggorengan yang menggunakan tungku besar dan dengan pembakaran kayu bakar menyebabkan polusi asap pada ruang produksi, hal tersebut menyebabkan jelaga hitam. Jelaga tersebut selain mengotori tempat produksi dapat juga berpotensi mengkontaminasi produk. Sehingga jelaga tersebut dapat disentralkan dengan penggunaan cerobong untuk dikeluarkan. 


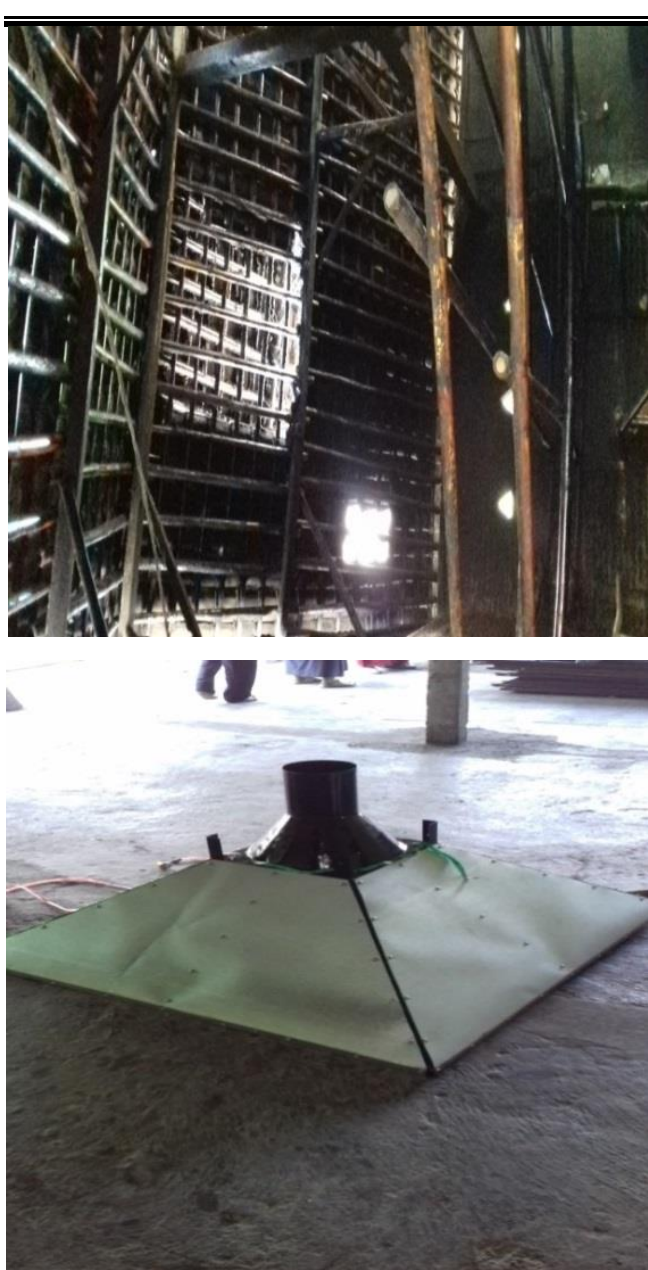

Gambar 2. Alat produksi yang masih konvensional sehingga aspek kehigienisan dan keamanan kurang begitu diperhatikan

Gambar 2 menunjukan prototype cerobong asap yang akan digunakan pada UKM mitra. Cerobong tersebut merupakan salah satu teknologi tepat guna, yang mudah dibuat dan digunakan. Selain itu cerobong asap tersebut cukup murah untuk dibuat, karena didisain sendiri, serta penggunaan material yang mudah didapat. Hampir semua bengkel teknik dapat membuat hal tersebut. Penggunaan alat semi mekanis dalam proses pembuatan karak untuk meminimalkan penggunaan tenaga manual sehingga faktor kebersihan dapat lebih terjaga. Hal tersebut dilakukan dalam rangka melaksanakan Peraturan Menteri (Permen) Perindustrian RI Nomor 75/M-IND/PER/7/2010 tentang Manfaat Pedoman Penerapan CPPOB (Cara Produksi Pangan Olahan yang Baik) untuk menghasilkan pangan yang bermutu dan aman serta sesuai dengan tuntutan konsumen.

\section{KESIMPULAN DAN SARAN}

\section{A. Kesimpulan}

1. Pelatihan pengetahuan pengusaha karak tentang keamanan karak yang diproduksinya

2. Peralatan untuk peningkatan sanitasi dan higienitas proses produksi karak

\section{Saran}

Mitra dapat melakukan perbaikan aspek sanitasi dengan segera, dari segala aspek agar proses produksi dapat segera mencapai syarat sesuai dengan GMP.

\section{DAFTAR PUSTAKA}

Astika, Mona. 2015. Formulasi Pembuatan Kerupuk Karak Dengan Penambahan Sodium Tripolyphosphate (STPP). Naskah Publikasi. Universitas Muhammadiyah Surakarta.

BSN [Badan Standar Nasional] Indonesia. 1996. Kerupuk 
Bara Yudhistira, I6M Pengusaha KerupukKarakdi Desa Dukuh untukMeningkatkan Kualitas Makanan Sehat dan Penerapan Inovasi Yeknologi Tepat Guna

ISSN : 1979-861X

e-ISSN : 2549-1555

Beras. SNI 01-4307-1996.

Jakarta.

Peraturan Menteri (Permen)

Perindustrian RI. 2010.

Manfaat Pedoman

Penerapan CPPOB (Cara

Produksi Pangan Olahan

yang Baik). Jakarta. 